\title{
LENTNER CSABA: RENDSZERVÁLTÁS ÉS PÉNZÜGYPOLITIKA
}

\author{
(Akadémia Kiadó, Budapest, 2005, 375 o.)
}

\section{CSERMÁK KÁROLY}

Nemrég látott napvilágot Lentner Csaba neves pénzügyi közgazdász (a NyugatMagyarországi Egyetem KTK dékán-helyettese, intézetigazgató, egyetemi docens, számos cikk, tanulmány és könyv szerzője és társszerzője) „Rendszerváltás és pénzügypolitika" címü, az Akadémiai Kiadó gondozásában megjelent tanulmánykötete.

A könyv elsősorban szakembereknek és a pénzügytan különböző fakultásain már közgazdasági (alap)ismereteket szerzett hallgatóknak szól. Azonban haszonnal forgathatja ezt a mủvet minden olyan olvasó, akit egyrészt érdekelnek a pénzügy rejtelmei, másrészt a kialakult véleményéhez kaphat további instrukciókat, ténybeli adatokat.

A szerző nem kevesebbre vállalkozott, mint arra, hogy figyelemmel kísérje a magyarországi, 1989. évi rendszerváltástól napjainkig lezajlott, a gazdaság egészét átfogó pénzügypolitikát, annak hibáival együtt. Mindemellett felvázolva a lehetséges megoldásokat, amelyeket párt-attitüdöktöl függetlenül bármelyik hatalmi struktúra beépíthet a politikai eszköztárába.

A könyv tizenkilenc önálló tanulmányként is megjelent aktualizált részbỏl áll, mely egybeszerkesztett formában is teljes egészet alkot. Sőt(!), ez teszi még jobban átláthatóvá az egyes témák esetleg megválaszolatlan, vagy összefüggéseiben, komplexitásában nem magától értetődő kérdéseit.

A könyv írója sorra veszi mindazokat a sarkalatos pénzügypolitikai kérdéseket, amelyek döntő hatással voltak (vannak) a jelen Magyarországának nem igazán szívderítő helyzetére. Nem is beszélve a napjainkban zajló EU-s tragikus ,fordulatokról", amelyek alapjaiban rengették meg az öreg kontinens nagy reményekkel kecsegtetỏ brüsszeli intézményrendszerét és költségvetési politikáját.

A könyv egyes tanulmányainak végkicsengései valahol sejttették ezeket az ott (is) feszülő problémákat, amelyeket valóban az alapjaitól kell újra- és átgondolni. Cél, hogy valóban egy olyan európai politikai-gazdasági-pénzügyi együttmủködési rendszer jöhessen létre, amely általános fejlödési, növekedési pályára állítja az EU-t, létrehozva ezzel egy olyan stabil pénzügyi-gazdasági potenciált, mely nemcsak hogy kiállja a próbát Japán és föleg az USA eróteljes -mindenre kiterjedő - hegemóniájával szemben, hanem méltó verseny(vetély)társává is válhat ezeknek a régióknak.

Szól a szerző a hazai privatizációról, amely mára már „a teljes kifulladás jeleit mutatja". Foglalkozik az agrárium helyzetével, annak finanszírozhatóságával, nem feledtetve azt a tényt, hogy mára már a mezőgazdasági ágazat kevesebb, mint 4\%-át adja a GDP-nek és ca. 8\%-át az összes exportunknak, és ennek megfelelöen csökkent az ebben az ágazatban dolgozók aránya az összes regisztráltan foglalkoztatot- 
takhoz viszonyítva, kb. 6\%-ra! Ennek ellenére, vagy éppen ezért, ismerve a magyar gazdaságföldrajzi adottságokat, helye és szerepe kell, hogy, legyen a magyar agráriumnak, úgy a bel-, mind a külpiacokon is! Ennek megjelöli finanszírozhatósági lehetőségeit, a birtokméretekhez igazodó agrárfinanszírozási rendszer kialakítását, a közraktározás és a lízingelés jelentőségét is.

Természetesen ,kiemelt” hangsúllyal szerepel az adópolitika. Ez a fejezet foglalkozik a közvetett adók (áfa, fogyasztási adó, jövedéki adó) és a közvetlen adók (kiemelten: SZJA, TAO, EVA stb.) csökkentésének, átstruktúrálásának és egyszersmind egyszerübb és áttekinthetöbb „,változatainak” szükségszerüségeivel is. Ennek végső célja, a gazdaság szereplöi (gazdasági társaságok és természetes személyek) jövedelemviszonyainak a javítása, ami viszont a GDP tartós növekedését (is) igényli.

Ráirányítja a figyelmet a kétszintủ bankrendszer 1987-töl lezajlott kialakulására és fejlödésére, és az EU-s elvárásoknak történő megfelelési igényre, továbbá arra a tényre, hogy a magyar kereskedelmi bankok több mint 60\%-ban külföldi tulajdonosi háttérrel müködnek. A pénzintézeti szektor további „szereplői” az állami tulajdonú fejlesztési pénzintézetek és az alacsony tökeerövel és hiteligényekkel rendelkező vidéki takarékszövetkezetek.

Az MNB megváltozott szerepköre a maastrichti „szellemnek” megfelelően a reálszektor refinanszírozásából és az államháztartás finanszírozásából történö teljes kiválását jelentette. A szerző áttekintést ad az arany szerepéről, megjegyezve azt, hogy míg - jellemzően - az EU-s országok eladják aranykészletük nagy részét (Magyarország az 1989. évi 65 tonnás aranykészletét 1992 októberére fokozatosan 3 tonnára(!) csökkentette), addig az USA megtartotta 8200 tonnás(!) aranytartalékát. Napjainkra az arany demonetizálódik, és a reálgazdasági jövedelmezőségi folyamatoktól olyan mértékü a pénzszféra relatív értékteremtö, derivatív ügyleteinek a volumene, hogy a szerző szerint ez 2010-re akár százszorosa(!) is lehet az előzőnek. Ez pedig óhatatlanul magában hordozza ,egy világméretú pénzügyi összeomlás lehetőségét".

Lentner kitér a hazai közgazdasági felsőoktatáson, a kis- és középvállalkozások finanszírozhatóságának kérdésein, a Széchenyi (Nemzeti Fejlesztési) Terv jelentöségén át a müködőtőke-befektetések néhány sajátosságaira, és az úgynevezett „magyar modell" elönyeire és hátrányaira is.

Vitathatatlan, hogy ,a magyar nemzetgazdaság modernizációját a külfölditókebefektetések alapvetően meghatározták". Ennek mértéke mára már elenyésző, így a minőségi tőkevonzási feltételeket szükséges kialakítani, mutat rá a szerző.

A könyv több ,fejezetében” is óhatatlanul szembekerülünk a magyar államháztartás egyre nagyobb mértékü eladósodásának kérdéseivel, mely fokozott kiszolgáltatottságot jelent a nemzetközi tőkének, elöidézve ezzel a teljes gazdasági-pénzügyi ellehetetlenülés folyamatának felerősödését...

Remélhetőleg sikerült ráirányítani a figyelmet e néhány kiragadott példával is erre a nagyszerü kiadványra, amelyet ajánlok minden, a téma iránt érdeklődő olvasónak nem pusztán „csak” elolvasásra, hanem további gondolatébresztőként is. 